\title{
ロ腔癌におけるオトガイトリンパ節転移の臨床病理学的検討
}

\author{
本間義郎・木下靫彦・井上聡・河原健司
}

葛原武・中村昌幸・水谷成孝・田畑利章

新藤潤一・志村介三

\section{Clinicopathological study of submental lymph node metastasis from oral cancer}

\author{
Yoshiro Honma - Yukihiko Kinoshita - Satoshi Inoue - Kenji Kawahara \\ Takeshi Kuzuhara $\cdot$ Masayuki NaKamura - Naritaka MizutanI \\ Toshifumi Tabata $\cdot$ Junichi Shindo $\cdot$ Kaizo Shimura
}

\begin{abstract}
A clinicopathological study was performed on 9 cases of metastasis of the oral cancer to the submental lymph node experienced in our department. As a result, it was found that the metastasis was extensive in these cases with a high incidence of recurrence in the contralateral cervical region. Compared with the submandibular lymph node, the tumor tended to develop outside the lymph node in the early stage for metastatic lesions of the submental lymph node, and the recurrence after radical neck dissection was also more frequently observed in the submental region. Therefore, the metastatic aspect in the submental lymph node apparently differed from that of the submandibular lymph node.

Thus, a more elaborate treatment should be performed in such cases.
\end{abstract}

Key words: submental lymph node (オトガイ下リンペ節), metastasis (転移), oral cancer (ロ 腔癌)

緒

頭頸部癌の頸部リンパ節部位に関して,オトガイ下リ ンパ節は，UICC のレベル分類 では䫇下リン・゙節とと もにレベル1に分類されており，実際の頸部リンパ節 転移に関する報告にもこれと同様に分類したものが多 (2) しかし，オトガイ下部に扣けるリンパの流れなど は他の頸部リン人節と異なる解剖学的特徵があり、また 最近, オトカイイトンン゚節に転移を認めた症例は，たと え転移が上頸部に限局していても予後不良であるとの報 告 ${ }^{3,4)}$ もられるなど，本リンパ節転移の臨床的評価に

神奈川菌科大学口腔外科学教室 （主任：志村介三教授）

Department of Oral Surgery, Kanagawa Dental College (Chief: Prof. Kaizo Shimura)

受付日：平成 2 年 3 月 26 日
ついて，再考すべきことがある.

今回，われわれはオトガイ下リンパ節転移が組織学的 に確認できた口腔癌 9 例について, 臨床病理学的検討を 加えた.

対 象

対象は1974年から1989年までに当科で診断，治療を行 った口腔癌 265 例のらち, 組織学的にオトガイ下リンパ 節転移が確認できた 9 症例である。症例の内訳は, 性別 では男性 6 例, 女性 3 例で，年秢は46藏から76歳，平均 57.1 歳である。原発部位は舌 4 例, 煩粘膜 3 例, 口底 2 例である。 TNM 分類では $\mathrm{T} 0$ が 1 例, $\mathrm{T} 1$ が 2 例, T2 が 4 例, T4 が 2 例で, N0が 3 例, N1 が 4 例, N2b が 1 例, N2c が 1 例で, 全例 M0 であった。臨床病期は Stage I が 2 例, Stage II が 1 例, Stage III が 3 例, Stage IVが 3 例であった。組織型は扁平上皮癌が 8 例, 
表 1 対象症例

\begin{tabular}{|c|c|c|c|c|c|}
\hline & 性 & 年齢 & 原発部位 & 分類 & $x$ \\
\hline 1 & 男 & 5 & f & & 扁平上 \\
\hline 2 & 男 & 70 & 口底 & Mo & 扁平上 \\
\hline 3 & 女 & 45 & 千. & $\mathrm{T} 1$ & 扁平上 \\
\hline 4 & 女 & 76 & 4 & 10 & $G-I$ \\
\hline 5 & 男 & 46 & 5 & & $(-1)$ \\
\hline 6 & 男 & 4 & 舌 & $\mathrm{T} 4$ & 政 \\
\hline 7 & 女 & 75 & 煩粘膜 & $\mathrm{T} 2$ & 扁平上 \\
\hline 8 & 男 & 49 & 煩粘膜 & $\mathrm{T} 4$ & 扁平上皮瘦 $(\mathrm{G}-\mathbb{I}$ \\
\hline 9 & 男 & 56 & 底 & T2N1M0 & 末分化癌 \\
\hline
\end{tabular}

未分化癌 1 例であった。扁平上皮癌症例の WHO 組織 分類は Grade I が 4 例, Grade II が 3 例, Grade III が 1 例であった(表 1)。頸部郭清術式は根治的全頸部郭清術 が 6 例，上頸部郭清術が 3 例であった。 また全頸部郭清 術例でオトガイ下リンパ節転移のない40例を対象として 用いた。なお頸部リンパ節の解剖学的分類については解 剖学用語 $\mathrm{P}, \mathrm{N}, \mathrm{A}^{5)}$, に準じ，オトガイ下リンパ節，䪽 下リンパ節, 頸静脈二腹筋リンパ節, 頸静脈肩甲舌骨筋

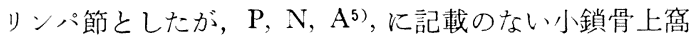
部と外側頸部のリンパ節については井上 ${ }^{6)}$ の分類に從 い, 鎖骨上裔前群，後群，側頸部リンパ節に分類した。

\section{結果}

\section{1. 原発腫瘍の占拠部位}

舌側縁に限局したものが 3 例, 頓粘膜に限局したもの が 2 例, 一側の口底に限局したものが 2 例, 可動部舌全 体から口底に及ぶもの 1 例, 煩粘膜を広範に進展しさら に煩部皮府に浸潤したもの1例で(図１）, 下唇正中粘膜 部, 下顎前雨部崡肉に原発および進展した症例は認めら れなかった。

\section{2. リンパ節転移様式}

今回の 9 症例に括ける組織学的な転移部位では, オト ガイ下リンパ節のみに限局した症例はなく, いずれもオ トガイ下リンパ節の汪かに，顩下リンパ節転移を伴らも のが 3 例, 頸静脈二筋リンパ節を伴うものが 1 例, 顎下 リンパ節および頸静脈二腹筋リンパ節を伴 5 ものが 1 例, 顎下と頸静脈二腹筋リンパ節および頸静脈肩甲舌骨

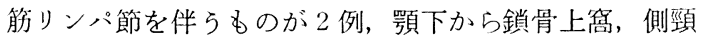
部にわたるすべての部位に認められたものが 1 例, 患側 は顎下から鎖骨上窩後群まで，かつ反対側の顎下および 頸静脈肩甲舌骨筋リンパ節に及んだものが 1 例であった (表 2).

これら 9 症例とオトガイ下リンパ節転移のない全頸部 郭清術 40 例と転移部位数を比較すると, 後者では転移が

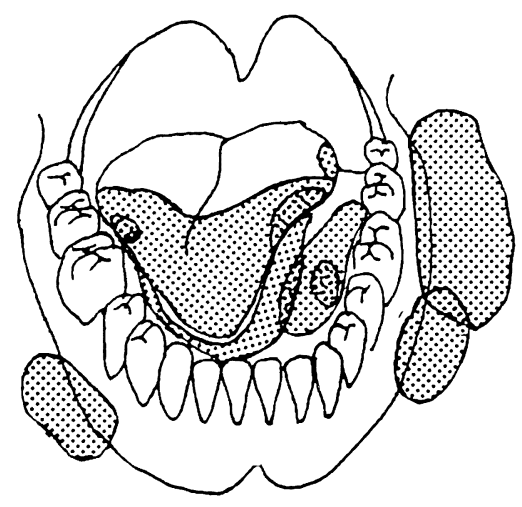

図 1 原発腫瑒の占拠部位

1 部位に限局するものが26例， 2 部位に及ぶものが 6 例, 3 部位が 3 例, 4 部位が 3 例, 5 部位以上が 2 例て あった。一方, 前者では 1 部位に限局する症例はなく, 2 部位にわたるものが 1 例， 3 部位が 3 例， 4 部位が 3 例, 5 部位以上が 2 例で, オトガイ下リンパ節転移を伴 与症例には広範な転移例が多く認められた(表了).

また䫈下リンパ節とオトガイ下リンパ節における転移 腫瘍の組織学的進展度について以下のごとく 4 段階に分 類した (図 2$)^{7)}$ その結果, 対象とした顎下リンパ節転 移宩では50個中, 転移腫瘍が輸入リンパ管や周縁洞にの 又限局して認められる Stage I が 3 個, 転移腫瘍が周緣 洞から傍皮質や中間洞に進展している Stage II が12個, 転移腫瘍によりリンパ組織の大部分が消失し, 置換され ている Stage III が24個, 転移腫瘍がリンパ節外に進展し ている StageIVが11個であった。一方，オトガイ下リン パ節13個では, Stage I が 1 個, Stage II が1 個, Stage IIIか3 3 個, Stage IV が 8 個で, 同一レベル内でもオトガ イ下リンパ節には顎下リンバ節に比べ転移腫瘍の組織学 的進展度の高いものが多い傾向であった（表 4).

\section{3. 転 帰}

9 症例のうち原発巣がコントロールされているにもか かわらず，頸部再発をきたしたものは6 例であった。再 発部位は，患側ではオトガイ下部が 3 例であり，頸静脈 二腹筋部, 頸静脈肩甲舌骨矣部, 鎖骨上窝前方部, 鎖骨 上窝後方部が各 1 例，また反対側への再発は 3 例で，顎 下部，頸静脈肩甲舌骨笳部，鎖骨上伶前方部，前頸部が 各 1 例であった(表 2).なおオトガイ下部の 3 例は初回 手術時, いずれも転移紧の組織学的進展度は Stage IVで あった。頸部再発に対しては, 上頸部のものには再手術 や組織内照射が行われ，コントロールされたが，中頸部 や下頸部のものにはコントロールされないものが多く認 められた。

カプランマイヤー法による生存率では, オトカイトリ ンパ節転移例では 3 年生存率は $33.3 \%, 5$ 年生存率 22.2 
表 2 組織学的転移部位と再発, 転帰

\begin{tabular}{|c|c|c|c|}
\hline 症例 & 組織学的転移部位 & 再発部位 & 転帰 \\
\hline 1 & オ下+頸二腹 & （反）鎖上前, 前頸部 & 死（24か月） \\
\hline 2 & オ下+顎下+頻二腹 + 钼局舌 & （反）頸肩舌 & 死（31か月） \\
\hline 3 & 才下十額下＋頸二腹＋頸高舌＋镍上前＋镍上後＋㑡頸 & 鎖上後 & 死（17か月） \\
\hline 4 & オ十+顎下 & オ下, 頸二腹, 頸扁舌 & 死（37か月） \\
\hline 5 & オ下+頻下 & オ下（反）顎下 & 生(124か月) \\
\hline 6 & 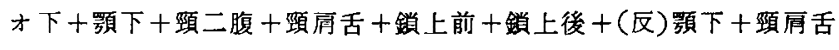 & 不明 & 死 ( 3 か月) \\
\hline 7 & オ下＋顎下 & 原発巣 & 生（70か月） \\
\hline 8 & オ下+顎下＋頸二腹十頸有舌 & 不明 & 死（6か月） \\
\hline 9 & オ下+顎下十頸二腹 & 鎖上前 & 死（17か月） \\
\hline
\end{tabular}

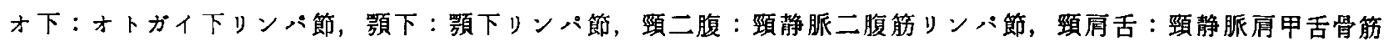
リンパ節，鎖上前：鎖骨上窩リンパ節前群，鎖上後：鎖骨上窩リンパ節後群，㑡頸：側頸リンパ節

表 3 転移部位

\begin{tabular}{l|c|c}
\hline 転移部位 & オトガイ下例 & 全頸部郭清例* \\
\hline 1 部位 & 0 例 & 26 例 \\
2 & 1 & 6 \\
3 & 3 & 3 \\
4 & 3 & 3 \\
5 部位 & 2 & 2 \\
\hline & 9 例 & 40 例 \\
\hline
\end{tabular}

*オトガイ下リンパ節転移例を除く

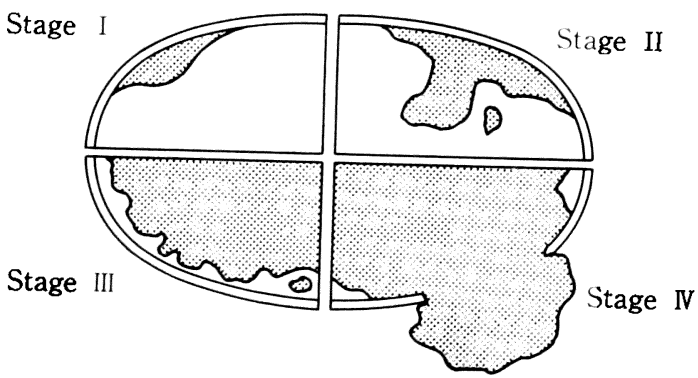

図 2 転移嗹痬の組䄉学的進展度

\%，対象としたオトガイ下リンパ節転移のない全頸部郭 清術症例では 3 年65.1\%，5 年57.9\%であり，Z検定に て危険率 $5 \%$ で両群間に有為差が認められた(図了).

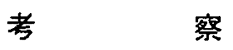

口腔癌に持けるオトガイ下リンパ節転移頻度につい $\tau$, Lindberg ${ }^{9)}$ は舌癌302例中 7 例，口底癌258例中 5 例
表 4 転移腫煬の組織学的進展度

\begin{tabular}{c|c|c}
\hline 部 位 & オトガイ下 & 顎 下 \\
\hline Stage I & 1 個 & 3 個 \\
Stage II & 1 & 12 \\
Stage II & 3 & 24 \\
Stage IV & 8 & 11 \\
\hline & 13 個 & 50 個 \\
\hline
\end{tabular}

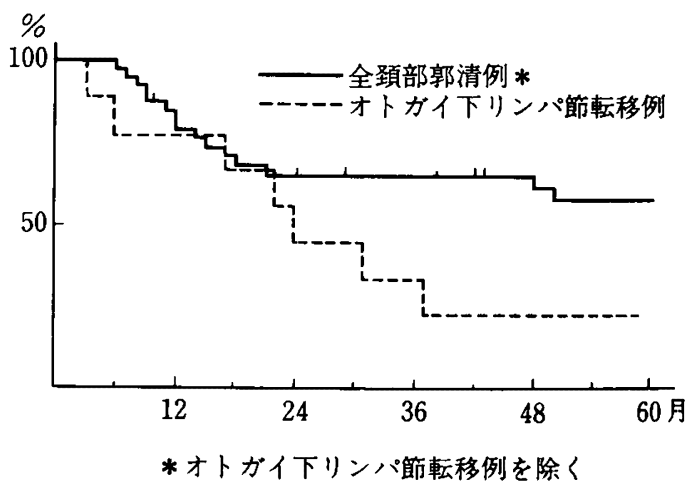

図 3 生存率

にのみ臨床的な転移を認めているにすぎない，頸部郭清 術例に拈ける本リンパ節転移頻度は, 予防的頸部郭清術 の割合いにより左右されるが概して低く， pN (十) 例中 の $9 \sim 12 \%$ と報告?,8 11) されている.

小野ら゙ははとえ転移が上頸部に限局していても，才 トガイ下リンパ節転移を認めた症例は尒後不良であると 述べているが，各施設に打ける症例数が比較的少ないこ と ${ }^{12)}$ ，多くの報告が転移部位として韻下ンンパ節と一括 


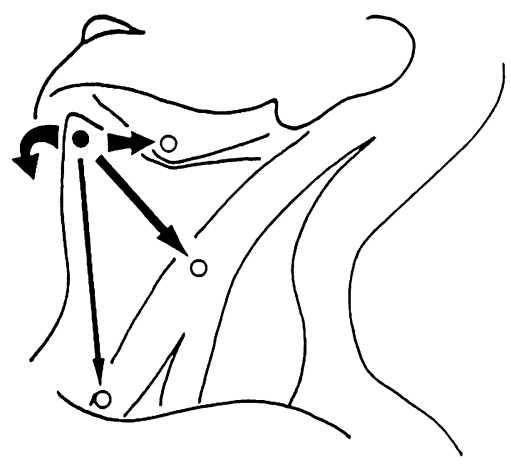

図 4 オトガイトリン八節からの輸出管

にして扱っていることから²)，才トカイ下リンハ節転移 の㬰相には不明な点が多く，臨床的な評価や対応につい ては明確にされていない。

解剖学的にはオトカイイリンパ節は顎二腹笳前腹と舌 骨からなるオトガイ下三角に存在し, 通常, 米粒大で, 2 〜 個存在するとされている ${ }^{13)}$. しかし，研究者によ っては本リンパ節は, 左右 2 群 $^{14)}$, 上下 2 群 ${ }^{15)}$, 前中後 3 群 $^{16)}$ に分類するもの，個数も $1 \sim 2$ 個 $^{14,17}$ から $1 \sim 11$ 個とするもの ${ }^{15)}$ までかなり差異がみられる。本りンパ節 は主としてオトガイ下部や下唇正中部の皮虏，下顎前蒾 部齿肉, 下唇正中粘膜, 舌尖部からのリンパ管が流入す るが ${ }^{13,19)}$, 口底前方 ${ }^{15)}$, 舌縁 ${ }^{18,20)}$, 舌体 ${ }^{19,20)}$, 煩粘膜 ${ }^{14}$ からの流入を認めたとの報告もある。才トガイトリンパ 節からの輸出リンパ管は前顎下リンパ節，頸静脈肩甲舌 骨笳リンパ節，小鎖骨上畕（鎖骨上盆リンパ節前群）の リンパ節に流入するとされている(図 4$)^{13)}$ 。また，オ卜 ガイ下リンパ節には，しばしば反対側からのリンパ管が 流入したり，反対側のリンパ節に輸出管を出している （正中交叉）ことが知られている13,17,18,20).

文献的には，本リンパ節転移を生じた症例の原発部位 としては舌が最も多く ${ }^{4,9)}$ ，ついで口底 ${ }^{9 \sim 11,21)}$ ，下䋶歯 肉 ${ }^{9,11)}$, 煩粘膜 ${ }^{9)}$ の報告がみられる。 今回の症例でも舌 が 9 例中 4 例を占めていたが，煩粘膜が 3 例と比較的多 くみられたことが特徵的である。このほか，口底が 2 例 であり，下顎歯肉，上顎歯肉，上顎洞原発例には才卜カ イ下リンパ節は認められなかった。著者らが文献的に検 索しえた範囲では，上顎歯肉，口蓋，上顎洞原発例から オトカイトリンパ節に転移をきたした症例は認められて いない.

今回の各症例における原発腫盼の占拠部位が通常の才 トガイ下リンパ節の輸入領域であったものは 9 例中, 症 例 6 の 1 例にすぎず，残りの 8 例はこれらの領域外に原 発，進展していたものであった。したがってこれら8例 にオトガイ下リンパ節転移が生じた理由としては解剖学 的な個体差も無視できないが，いずれも他の上頸部にり
ンパ䬦転移がみられたことから、これらの他部位の転移 稿の增大により, リンバ性塞栓が起こり, リンパ流の異 常が生じ，近行性ないし副側路を経てオトガイ下リンパ 節に転移をきたした可能性が考兄られる4．

一般に，口腔癌の頸部りンハ節転移の特徴としては， 買下ないし頸静脈二腹筋りンハ節の上頸部に集中するこ とが知られている ${ }^{7,9-12)}$ が，今四のオドイ下リンパ節 転移症例の 9 例中 8 例は転移が 3 部位以上に及几でお り，広範な転移傾向が認められた。换言すればオトガイ 下リンパ節に転移が少られた場合には，たと瀶床的に 触知しえなくても他部位のリンパ節転移を伴っている可 能性が高いことを示しているといえよう。

さらに 9 例中 3 例に頸部晫清術後, 区対側頸部再発が みられたことは，オトガイ下部におけるリンパの流れの 特殊性 ${ }^{13,17,19,20,22)}$ によるものと考光られた。すなわち片 山社によれば, オトガイ下リンパ節は左右互いに連結, かつ反対側のリンパ管を収めることもまれではなく，偏 在している場合は反対側のリンパ流域のリンパ管をたび たび受注し，輸出管は反対側の流出域に向かうこともま れではない、したがって，本リンパ節転移例では反対側

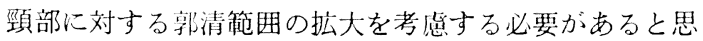
われた。

また最近，転移腫瘦のリンパ節被膜外への進展を重要 な子後因子として指摘する報告 ${ }^{23,24)}$ が多くみられる。才 トガイ下リンパ節転移巣についてみると, UICC の分 類1)で同じレベル1に属する顎下リンパ節の転移栄に比 ベ, Stage IV のリンハ節外への進展を示すものが多く, これが $2 / 3$ を占めていることが特徴的であった。この理 由としては，オトガイ下リンパ節は通常，米粒大で，転 移をきたしても㴿下リンパ節のよらに大きく腫脹するこ とがなく25)，触診で臨床的に転移を認めた時点ではすで にリンパ節外進展を示しているものが多いためと考えら れた。このことはオトガイ下部が触診や护清の比較的容 易な部位であるにもかかわらず，9 例中 3 例にこの部の 再発が認められたことの理由の1つとも考光られ，才ト カイ下部のより注意深い郭清の必要性が示唆された。

\section{結論}

当科で経験した口腔癌のオトカイ下リンパ節転移 9 症 例について, 臨床病理学的検討を加えた。その結果, 本 リンパ節転移例は転移が広範であり，反対侧頸部の再発 も多く認められた。 また顎下リンパ節に比べ，才トカイ 下リンバ節の転移巣では腫瘍が早期にリンパ節外に進展 する傾向であり，頸部郭清後もこの部における再発が多 く認められた。したがって本りンパ節における転移様相 は，靧下リンパ節の転移様相とはあきらかな相遣がみら れ，より慎重な症例への対応が望まれる。 
本諭文の要旨は第40回日本口腔科学会総会（1986年, 稫岡市）に扣いて発表した。

\section{引用文 献}

1) Harmner, M.H. (edit.): TNM classification of malignant tumors. WHO, Geneva, 1978, p. 18-19.

2) Spiro, R.H., Alfson, A.E., et al.: Cervical node metastasis from epidermoid carcinoma of the oral cavity and oropharynx. Am J Surg 128: 562-567, 1973.

3）小野 勇, 嘿津邦雄, 他: 舌癌治療に打ける頸 部郭消㧓の評価。瘦の臨床 26：123-1301980.

4) 木下鞄彦, 本間義郎, 他: 舌癌症例の臨床病理 学的検討。一頸部リンパ節転移について一。 日 口外誌 31：1715-1721 1985.

5) 日本解剖学会編: 解剖学用語。第11版, 丸善, 東京, 1969, 148-149頁。

6）井上長生：日本人胎児深頚リンパ節の解剖学的 研究. その 1, 萪科学報 66: 511-521 1966.

7) 本間義郎：口腔癌の頸部リンパ節転移に関する 研究. 日口外誌 28：1667-1684 1982.

8) Lindberg, R.: Distribution of cervial lymph node metastases from squamous cell carcinoma of the upper respiratory and digeestive tracts. Cancer 29: 1446-1449 1972.

9) 岡本学, 大関悟, 他：口腔癌に扣ける頸部 郭清術施行例の検討。一钼部リンハ節転移様相 と予後一。 日外訰 31：554-562 1985.

10）新垣 晋：口腔領域悪性腫埸の頙部リンパ節転 移に関与る臨床病理学的研究。日口外誌 25 : 784-797 1979.

11）立花忠夫：口腔領域扁平上皮瘦の新部リンパ節 転移に関する臨床ならびに病理組䄳学的研究。
口病誌 $52:$ 513-536 1985.

12） TNM 分類研究頭頸部関係資料. 日本 TNM 分類委員会頭頸部小委員会編，1980，5頁，

13）上条雍彦口腔解剖学 3 , 第 5 版, アナトーム 社, 東京, 1973, 付 27-29頁.

14）飯田三郎. 邦人頸部淋巴管系統に関する解剖学 的研究. 解剖誌 7: 111-197 1934 .

15) Bartels，P.: 文献 17）から引用。

16) Rouviere, H.：支献 17）から引用.

17）忽那将愛編：日本人リンパ系解剖学。初版, 金 原出版, 東京, $1968,49,51,71$ 頁。

18）片山武夫：口腔及びその附近の淋巴管系統の解 剖学的研究。日迷科誌 30：647-770, 1937.

19) Hollinshead, W.H.: Anatomy for sugeron. 1 The head and neck. 2nd Ed, Hoeber Medical Division, New York, 1968, p 411-412, 427-428.

20) Haagensen, C.D., Feind, C.D., et al.. The spread of cancer in the lymphatics in cancer. 1st Ed, W.B. Saunders, Philadelphia, 1972, p 134-149.

21) Feind, C.R. and Cole, R.M.: Cancer of the floor of the mouth and its lymphatics spread. Am J Surg 116: 482-486 1968.

22) Feind, C.R. and Cole, R.M.: Contralateral spread of head and neck cancer. Am J Surg 118: 660-665 1969.

23) Snow, G.B., Annyas, A., et al.. Prognostic factors of neck node metastasis. Clin Otolaryngol 7 : 185-192 1982.

24) Johnson, J.T., Barnes, E.L., et al.: The extracapsular spread of tumors in cervical node metastasis. Arch Otolaryngol 107: 7257291981.

25）三橋䣲子：頭頸部瘦の頸部転移についての臨床 病理組織学的研究。日耳奥 71:621-639 1968. 